\title{
APPLIED SOLAR ENERGY IN THE REDUCTION OF THE POISON OF THE RICINUS COMMUNIS PIE
}

\author{
E. T. L. Cöuras Ford ${ }^{\mathrm{a}}$, \\ J. U. L. Mendes ${ }^{a}$, \\ and E. M. Souza ${ }^{b}$ \\ ${ }^{\mathrm{a}}$ Universidade Federal do Rio Grande do Norte \\ Pós-Graduação em Engenharia Mecânica \\ Centro Tecnologia \\ Av. Senador Salgado Filho \\ Campus Universitário, S/N \\ CEP. 59072-970, Natal, RN, Brasil \\ elmocouras@hotmail.com \\ b'Instituto de Educação Superior \\ Departamento de Engenharia e Administração \\ BR-230 , João Pessoa, PB, Brasil
}

\section{INTRODUCTION}

Ricinus communis is a type of grain, that has as main use the vegetable oil manufacture, and can be used to produce biodiesel. As by-product from this manufacture process comes the Ricinus communis pie which is used as fertilizing, as insecticidal and more recently as animal feed. Before, using it as animal food it is necessary submitting this pie to a process of elimination of a toxic material called ricinus, wich can induce death if ingested. Diverse studies and works were developed for the elimination of the ricinus, such as: dry heating with a $205{ }^{\circ} \mathrm{C}$ temperature, baking of the pie in flakes with chemical treatment, baking of the crushed pie changing the water after each boil, treatment with sterilizer, bath in chemical solution, among others. An innovation in this type of treatment is the elimination by solar energy, since it is clean, inexhaustible and economic, might be made through direct or indirect exposition, with forced or natural convection and, still, using solar drying concentrative type and plane collector type.

\section{THEORY}

Ricinus communis pie was used as material for analysis deriving from the process of vegetable oil manufacture by Bom-Brasil, a company headquartered in Salvador city - Brazil. It was conditioned in bags of $1 \mathrm{~kg}$, in the dry state, natural, and it did not present uniformity in its composition as it can be observed in the Fig. 1.

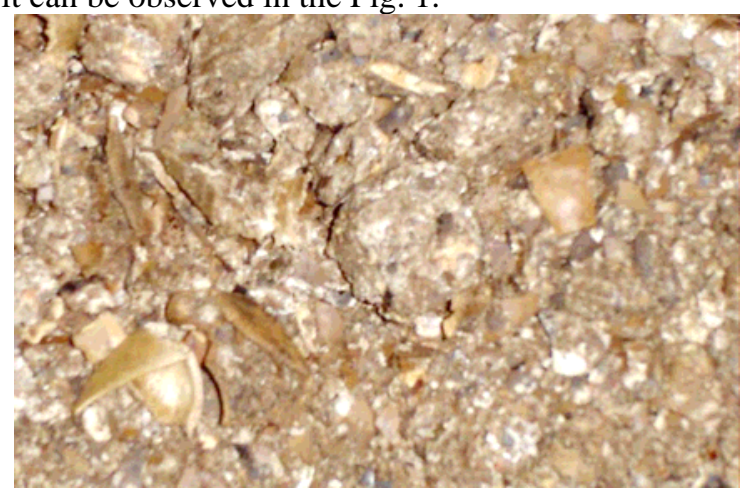

Figure 1. Pie of Ricinus communis.

A cylinder-parabolic concentrative solar drier with focal axle guided according to the east-west line was chosen as drying system. The system has an opening area of $1 \mathrm{~m}^{2}$ to capture the solar energy and a focal distance of $25 \mathrm{~cm}$. Its reflecting surface was composed by 22 plain mirror segments of $5 \mathrm{~cm}$ width per $1 \mathrm{~m}$ length. This system was set up on a base endowed by a mechanical device which made the manual tracking of the apparent movement of the sun (solar declination). In the focal region, that has $10 \mathrm{~cm}$ width and $1 \mathrm{~m}$ length, a gutter with greenhouse effect was fixed where the material was placed to be dried (Fig. 2; Fig. 3 and Fig. 4). Samples of the Ricinus communis pie have also been dried in a plain solar drier of direct exhibition made of masonry with $4 \mathrm{~m}$ length per $1 \mathrm{~m}$ width (Fig. 5). 


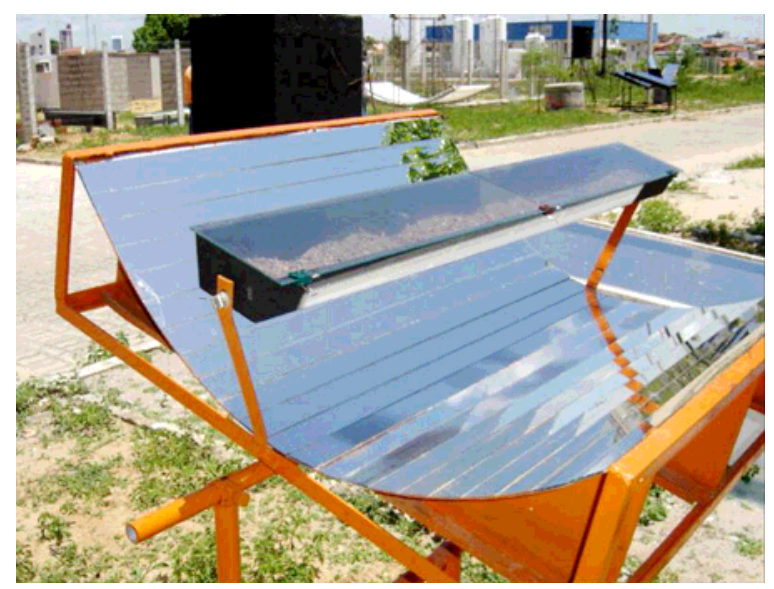

Figure 2. Cylinder-parabolic concentrator.

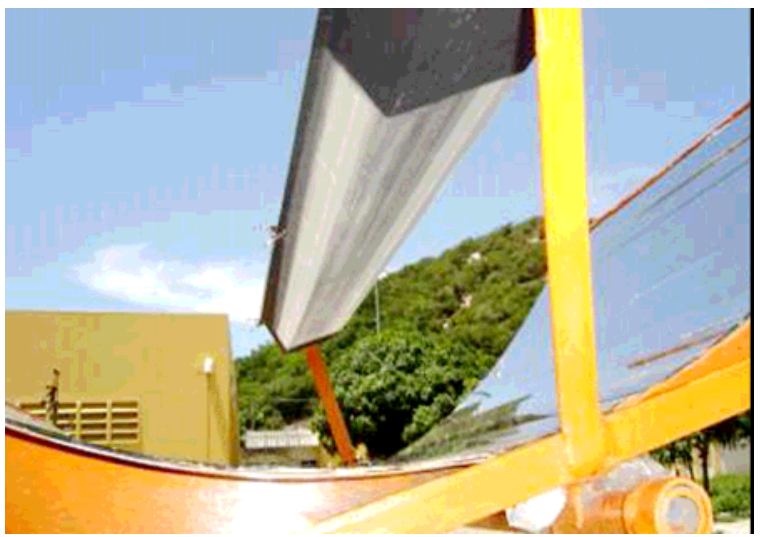

Figure 3. Absorber gutter in the system focus.

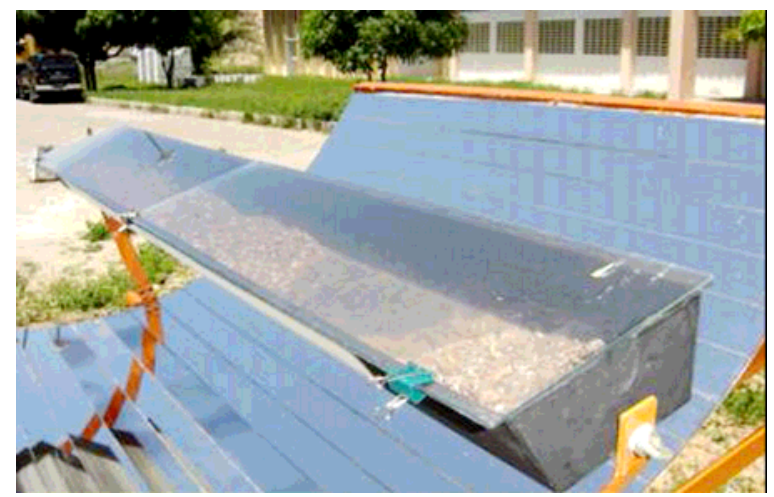

Figure 4. The system focus.

\section{EXPERIMENTS}

The samples, initially weighed (150 g each), were placed separately in groups of seven inside the absorber gutter of the concentrator and its temperatures were monitored in intervals of half an hour between 09 a.m. and 03 p.m., during thirteen consecutive days where the speeds of the wind and the relative humidity of the air were also monitored. The period of exposition to the heating varied from 0,5 h, 1 h, 2 h, 3 h, 4 h, 5 h, and 6 h from sample to sample, respectively. However in the plain solar collector the samples were dried in a period of 7 uninterrupted hours. Later, the samples were collected, weighed again and stored to be sent to the laboratory of the Embrapa Algodão in the city of Campina Grande - PB, responsible for the analysis of the ricina percentage. The samples submitted to the solar drying were sent to the Depto. of Chemistry from the Federal Fluminense University (UFF) - Rio de Janeiro and to the Embrapa Algodão - Paraíba, for the analysis of the percentage of ricina elimination. The method used by the UFF to determine the mass variation, percentile of ricinus elimination, was the spectrophotometry, whose results can be observed in table 1, for samples without chemical treatment. However the method used by Embrapa Algodão was electrophoresis where the concentration of ricinus for samples with and without chemical treatment were compared, as observed in Fig.6.

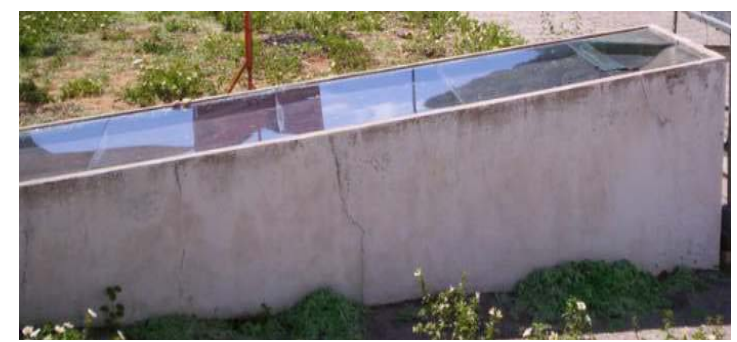

Figure 5. Solar plane drier.

\section{RESULTS AND DISCUSSION}

It was verified that, throughout the period of measuring, the temperatures of the samples placed in the absorber gutter of the cylinder-parabolic concentrator had varied from $353 \mathrm{~K}$ to $408 \mathrm{~K}$ (Fig.3.1). However, the temperatures of the samples placed in the plain solar collector had varied from $309 \mathrm{~K}$ to $359 \mathrm{~K}$ (Fig.3.2). Inside these temperature bands some samples without chemical treatment and with chemical treatment were randomly chosen so that the ricinus percentage reduction could be analyzed due to the influence of the heating, as shown in Table 1 and Fig. 6.

Two important conclusions can be observed by Table 1. The first one is that samples submitted to bigger temperature bands in a given period of time have bigger ricinus percentage reduction than samples submitted to smaller temperature bands in a period of approximately equal time, as it can be seen through the sample $(\mathrm{A} 0,5 \mathrm{e})$ that in half an hour varied its temperature from $383 \mathrm{~K}$ to $393 \mathrm{~K}$ and eliminated $36.2 \%$ of ricinus; more than the sample (A1c) that in one hour varied its temperature from $363 \mathrm{~K}$ to $378 \mathrm{~K}$, therefore a smaller temperature band, and eliminated a ricinus percentage smaller and equal to $26 \%$. The other conclusion is that samples submitted to smaller temperature bands but for long periods of sun exposition, have greater ricinus percentile reduction, as the sample (E3) example, that for a seven hour period of uninterrupted exposition to the sun varied its temperature from $311 \mathrm{~K}$ to $348 \mathrm{~K}$, eliminating $47 \%$ of ricinus from its composition; more than the observed percentage for the other samples. 
However, for the eletroforese method, one evidenced that samples submitted to chemical treatment have greater percentile of ricinus elimination than the samples not submitted to this treatment in the analyzed temperature band, and that is evidenced by the Fig. 6, where the samples with chemical treatment have longer dark bands than the samples without chemical treatment which is a characteristic of lighter samples, in other words, with minor ricinus percentile. However, the heating process of the Ricinus communis pie already eliminates a percentage of its total, inducing a smaller amount of chemical product for the elimination of the ricinus through this method, therefore, the use of solar heating also minimizes the costs of the chemical process.

It is concluded, therefore, that the heating of the ricinus communis pie consists in an important tool for the process of the ricinus elimination in order to be used as animal food and that the use of solar mechanisms becomes viable for such ends, not only from the technical point of view but mainly from the economic point of view.

Table 1. Summary of data referring to samples without chemical treatment.

\begin{tabular}{|c|c|c|c|c|c|}
\hline Sample & $\begin{array}{c}\text { Relante } \\
\text { Handidry of Air }\end{array}$ & $\begin{array}{l}\text { Tenaperanse } \\
\text { Varnabion }\end{array}$ & $\begin{array}{c}\text { Mass } \\
\text { Variation }\end{array}$ & $\begin{array}{c}\text { Percenale of Ricinss } \\
\text { Eliminavion }\end{array}$ & $\begin{array}{l}\text { Expositione } \\
\text { Time }\end{array}$ \\
\hline E3 & $96 \%$ & 311 to $348.4 \mathrm{~K}$ & $4.8 \%$ & $47 \%$ & 7 bouss \\
\hline A0.5e & $65 \%$ & 383 to $393 \mathrm{~K}$ & $6.0 \%$ & $36.2 \%$ & 0.5 bous \\
\hline $\mathrm{Alc}$ & $69 \%$ & 369 to $378 \mathrm{~K}$ & $86 \%$ & $26 \%$ & 1 bour \\
\hline
\end{tabular}

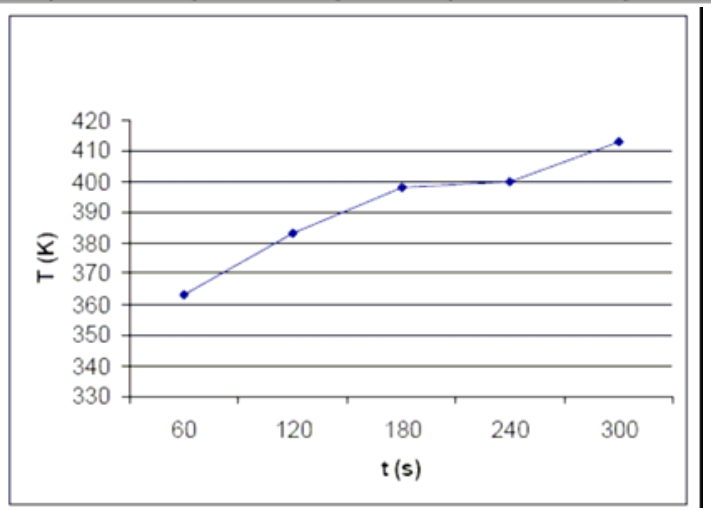

Figure 6. Variation of the temperature in the solar concentrator.

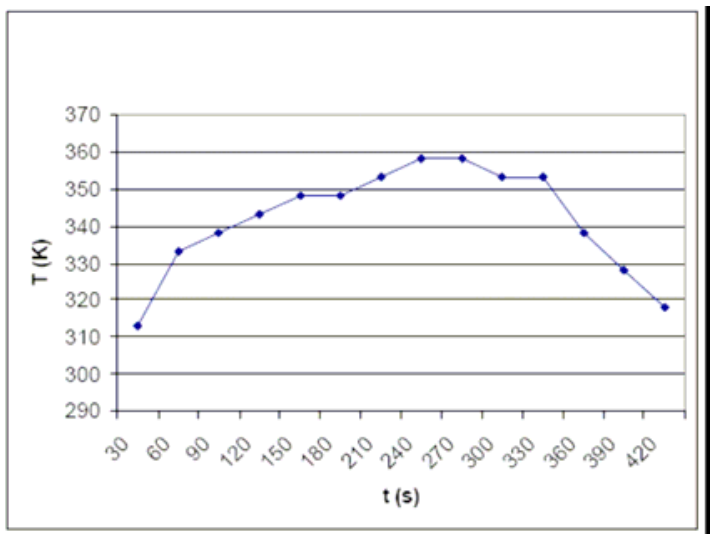

Figure 7. Variation of the temperature in the plain solar drier.

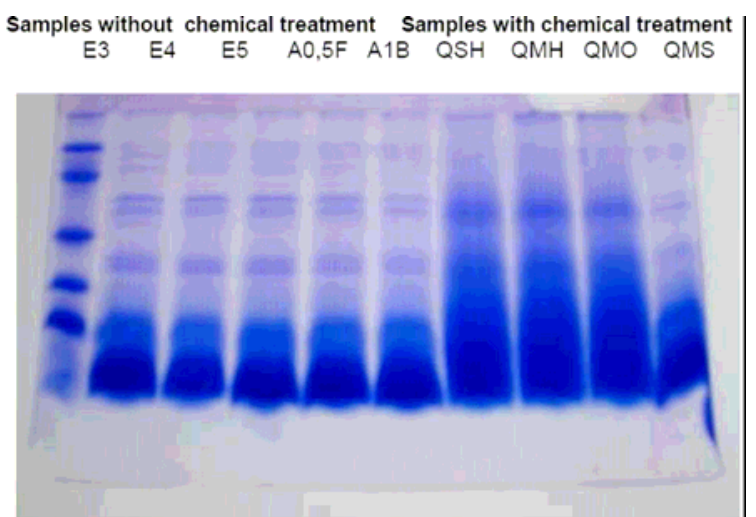

Figure 8. Amount of ricinus for samples with and without chemical treatment.

\section{ACKNOWLEDGEMENTS}

The authors thank the support obtained to promote the research:

- To CNPq / Capes.

- To Embrapa Algodão, Campina Grande - PB.

- To Chemical Department of Federal Fluminense University- RJ

- To Bom-Brasil, Salvador - BA.

\section{REFERENCES}

Anandan, A., Kumar, G. K. A., Ghosh, J., and Ramachandra, K, S., 2005, Effect of Different Physical and Chemical Treatments on Detoxification of Ricin in Castor Cake, Animal Feed Science and Tecnology, p. 120, pp. 159-168.

Azevedo, L., 2001, O Agronegócio da Mamona no Brasil, Embrapa Informação Tecnológica, 350p.

Beltrão, N. E. M., 2003, Torta de Mamona (Ricinus Communis L.): Fertilizante e Alimento, Comunicado Técnico $n^{\circ} 171$ Embrapa, ISSN 01020099 .

Bezerra, A. M., 2001, Aplicações Térmicas da Energia Solar, pp. 98-243.

Costa, F. X., Liv, S., Beltrão, N. E. M., Freire, R. M. M., Lucena, M. M. B., and Guimarães, B., 2004, Composição Química da Torta de Mamona, I Congresso Brasileiro de Mamona, Campina Grande-PB. 